DOI: $10.15290 /$ bsl.2017.11.03

\author{
Danuta Szajnert \\ Wydział Filologiczny \\ Uniwersytet Łódzki \\ e-mail: danuta.szajnert@uni.lodz.pl
}

\title{
Szwedzkie miejsca na drodze z Auschwitz - przystanek i przystań \\ (o narracjach Görana Rosenberga i Majgull Axelsson)
}

\begin{abstract}
Korzystam z każdej okazji, żeby pytać o drogę z Auschwitz, ponieważ każda droga z Auschwitz jest indywidualnym cudem sama w sobie, w odróżnieniu od drogi do Auschwitz, która jest kolektywnym piekłem dla wszystkich jednakowym. Droga z Auschwitz wykreśla najróżniejsze trajektorie, odbija ku całkiem nieprzewidywalnym celom i przecina zupełnie nieoczekiwane miejsca. [...] A ponieważ nieliczni, którzy żywi dotarli do kresu tej drogi, rzadko kiedy przebyli tę samą drogę, łatwo zdarza się, że drogi z Auschwitz popadają w zapomnienie ${ }^{1}$.
\end{abstract}

Dla Dawida Rosenberga, bohatera postpamięciowej, ale wolnej od celebracji posttraumy, narracji autorstwa jego syna Görana Rosenberga, zatytułowanej Krótki przystanek w drodze z Auschwitz, tym kresem było szwedzkie miasteczko Södertalje. Dla Miriam i zarazem nie Miriam, protagonistki powieści Majgull Axelsson Ja nie jestem Miriam² - miasteczko Nässjo, położone nieco dalej na południe, w Smalandii. W obu tych tekstach odpominane są drogi z Auschwitz i na różne sposoby tematyzowane loci, w których krócej lub dłużej przebywali i do których ostatecznie dotarli ocaleńcy. Pierwszy z nich nie zdołał uznać tego locum za własne. Ostatnie miejsce jego pobytu

\footnotetext{
1 G. Rosenberg, Krótki przystanek w drodze z Auschwitz, przeł. M. Kalinowski, Wołowiec 2014, s. 99-100. Dalej jako KP i numer strony w tekście głównym. Słuszność tego rozpoznania Rosenberga potwierdzać może choćby fakt znacznie mniejszej od Czy to jest człowiek popularności Rozejmu - opowieści Primo Leviego poświęconej w całości drodze z Auschwitz.

2 M. Axelsson, Ja nie jestem Miriam, przeł. H. Thylwe, Warszawa 2015. Dalej jako JNM i numer strony w tekście głównym.
} 
to kolejny - uwikłany notabene przez autora opowieści w ciąg złożonych figuracji - "przystanek" w niemożliwej do zakończenia i dlatego przerwanej samobójstwem podróży. Miriam natomiast zrobiła wszystko, by z miejsca, jakie zostało jej dane, uczynić bezpieczną „kryjówkę”, którą można nazwać przystanią.

Oboje znaleźli się w Szwecji dzięki słynnej, podjętej tuż przed końcem wojny, akcji tamtejszego Czerwonego Krzyża (czy ściślej: przypisanej w całości Szwedzkiemu Czerwonemu Krzyżowi) - choć Dawid Rosenberg nie bezpośrednio dzięki niej, później niż bohaterka powieści i nie bez problemów, bo Szwedzi nie kwapili się do przyjęcia osób, które nie były wcześniej obywatelami państw skandynawskich. Każdy z dwojga bohaterów próbuje urzeczywistnić inny projekt oswojenia przestrzeni, w której pozwolono mu się osiedlić. Sposoby jej doświadczania - w dużej mierze zależne od przeszłych doświadczeń i od klimatu społecznego ówczesnej Szwecji - odgrywają ważną rolę $\mathrm{w}$ tych projektach, uwikłanych w złożone kwestie tożsamościowe.

Tym, co wskazuje na pokrewieństwo między Rosenbergowską memorialno-intymistyczną opowieścią z elementami swoistego, instrumentowanego esejem reportażu i powieścią Axelsson są zatem miejsca i okoliczności historyczne, w jakich bohaterowie do tych miejsc trafili, pewna wspólnota ich migracyjnych losów. Jest to jednakże wspólnota limitowana przez różnicę etniczną o niebagatelnych konsekwencjach. Odmienne w obu tekstach formy narracyjnego i afektywnego profilowania doświadczenia przestrzennego wiążą się tyleż z niejednorodnym statusem genologicznym i poetyką owych tekstów, co właśnie z pochodzeniem etnicznym ich protagonistów.

Oto, jak przebiegała droga Dawida Rosenberga, znaczona coraz bardziej obco brzmiącymi toponimami: urodził się w Widawie, mieszkał w Łodzi, trafił do Litzmannstadt Getto, potem do Auschwitz. Z Auschwitz wywieziono go do Unterkommando Vechelde koło Braunschweig, następnie do Aussenlager Salzgitter-Watenstedt, Ravensbrück i Aussenlager Wöbbelin. Po wyzwoleniu znalazł się w amerykańskim szpitalu polowym w Ludvigslust, później w sanatorium w Schwerin i w obozie zbiorczym dla dipisów w Bergen-Belsen. Stamtąd wyjechał do Szwecji. Kwarantannę odbył w Lund, po czym został skierowany do "obozu dla obcokrajowców" [KP, s. 161] w smalandzkim Öreryd, następnie do obozu dla obcokrajowców Żydów (tak!) w Tappudden-Furudal. Jakiś czas przebywał w Alingsäs w zachodniej części Gotaländu, by wreszcie trafić do wspomnianego już Södertalje. 
Te nazwy - w większości nieistniejące $\mathrm{w}$ pamięci zbiorowej - wymienione przeze mnie $\mathrm{w}$ porządku chronologicznym, Rosenberg przywołuje (niektóre po wielokroć) $\mathrm{w}$ różnych miejscach swojego tekstu nie tyle $\mathrm{w}$ takt kolejnych odkryć dotyczących losów jego "chorego na Auschwitz" ojca, co raczej $\mathrm{w}$ zgodzie $\mathrm{z}$ epizodyczno-asocjacyjnym, mieszającym plany czasowe, rytmem własnej opowieści. Wywołanym $\mathrm{w}$ ten sposób miejscom przydaje różne charakterystyki, wykorzystując przy tym wiedzę wyczytaną z rozmaitych publicznych i osobistych dokumentów oraz to, co zobaczył podczas podróży podjętej śladem tej, którą przed laty pod przymusem odbył jego ojciec.

Rytm sprawozdania z tej podróży współtworzą enumeracje i melancholijne powtórzenia, pozbawione wiary $\mathrm{w}$ ich ocalający pamięć sens: listy zapomnianych niemieckich "obozów niewolniczej pracy na terenie między Hanowerem, Hamburgiem i Brunszwikiem" [KP, s. 104] i szwedzkich „obozów dla cudzoziemców”, położonych często gdzieś na uboczu w obawie, że „mrok niesiony" przez "klientów” tychże obozów - tak oficjalnie nazywano zgromadzonych $\mathrm{w}$ nich, okaleczonych niedawnymi doświadczeniami, przybyszów - „zainfekuje światłe społeczeństwo" [KP, s. 169] kraju nieznającego grozy wojny, eksterminacji, prześladowań.

„[Ś]ladem [...] drogi przez archipelag niemieckich obozów" wyrusza Rosenberg syn „z plonem badań Karla Liedkego w bagażu i jego mapą w ręku” [KP, s. 120]. Jest to, jak pisze - zwracając się do utraconego w dzieciństwie ojca, by w ten sposób stworzyć choćby namiastkę nigdy nieodbytej rozmowy o jego przeszłości -

jedyna istniejąca mapa twojej drogi z Auschwitz. Są tu daty i miejsca, i strzałki wskazujące kierunki podróży, i zaznaczony na zielono szlak plączący się, jakby z roztargnieniem, między wykropkowanymi na czerwono wyspami obozowego archipelagu [KP, s. 109].

Na niewyraźnej, czarno-białej reprodukcji nie sposób dojrzeć tych szczegółów. Karl Liedke, pół Polak, pół Niemiec - syn żołnierza Wermachtu - wyrysował tę mapkę, bo badając na zlecenie lokalnych władz historię przemysłu w Brunszwiku odkrył, kto i w jakich warunkach pracował podczas wojny $\mathrm{w}$ niemieckich, nie tylko brunszwickich, fabrykach. Do Büssingwerke w tym mieście „dostarczeni" zostali również, zdolni jeszcze do pracy, ostatni Żydzi z Auschwitz, wywiezieni tam z getta łódzkiego w sierpniu 1944 roku.

Przy pomocy Liedkego Rosenberg gromadzi porażające dane o podobozach ze swojej listy i ich ofiarach; o wykorzystujących je właścicielach i dyrektorach fabryk, którzy nie ponieśli za to żadnej kary; o obserwujących "codzienne przemarsze niewolników" [KP, s. 105] dobrze odżywionych i dobrze ubranych mieszkańcach idyllicznych miasteczek, i o tym między innymi, że 
w uroczym Ludwigslust Amerykanie uznali ich za współwinnych popełnionych zbrodni i ukarali, każąc im pogrzebać trupy z pobliskiego Aussenlager w miejskim parku - skalać ulubiony przez nich wycinek przestrzeni. Uroczystości żałobne ilustruje jedna z dołączonych do tekstu fotografii.

Decyzja, aby najpiękniejsze miejsce $\mathrm{w}$ Ludwigslust zamienić $\mathrm{w}$ miejsce pochówku i pamięci, jest odpowiedzią na pewną potrzebę. Ci dobrze odżywieni i dobrze ubrani mają dostać nauczkę, której nigdy nie zapomną. Już nigdy więcej nie będą mogli przechadzać się pod lipami w parku, aleją między pałacem a kościołem, nie pamiętając o zbrodniach popełnionych w Wöbbelin [KP, s. 143].

Jednakże wkrótce ta część Mekleburgii, w której jest położony Ludwigslust, przechodzi pod administracją sowiecką. Po paru latach - już w "pozbawionej historii Niemieckiej Republice Demokratycznej” - „białe krzyże i gwiazdy Dawida znikają" z grobów, a „bezwstydne kłamstwo [...] przykrywa pamięć jak gęsty, bujny trawnik" [KP, s. 144-145]. Nowe, granitowe, odporne na zniszczenie tablice, znaczące dawne miejsce pochówku ofiar obozu, zostają odsłonięte dopiero w maju 2001 r., ale nie z inicjatywy mieszkańców miasta, tylko Amerykanina, byłego kaprala 82. Dywizji Powietrznodesantowej, która przed laty wyzwoliła obóz. W przeddzień tej komemoracyjnej uroczystości „ulicami przechodzi pochód kilkuset neonazistów" [KP, s. 145] sławiących czyny SS.

Gdzie indziej Rosenberg odnotowuje, że Niemcy są skądinąd „nienaganni także w kwestii upamiętniania okropieństw”, których się dopuścili. „Wręcz wzruszająco nienaganni”. Każdy -,,jeśli dobrze poszuka" - może znaleźć w odpowiednim miejscu jakąś pamiątkową tabliczkę, pomniczek, pomnik, a czasem nawet „muzeum pamiątek” [KP, s. 108]. Być może nigdy nie umieszczono by ich wokół drogi z Auschwitz przebytej przez Dawida Rosenberga, gdyby „dr Liedke nie zjawił się tam, by swoimi wygrzebanymi w trudzie ułomkami, dokumentami, świadectwami utwardzić leżący pod nimi grząski grunt" [KP, s. 120]. Nieufność, z jaką Göran Rosenberg traktuje instytucjonalne, uwalniające od brzemienia rzeczywistej pamięci, praktyki komemoracyjne - świadczy o tym między innymi ironiczne profilowanie wzmianki o owych materialnych Erinnerungsstätten rozrzuconych w przestrzeni indywidualnie doświadczanej jako mnemotopiczna - nie dotyczy zatem jednostkowych zasług dla ich instalacji. Rekonstruując topografię ojcowskiej historii, syn próbuje (co ważne) ożywić fasadową pamięć niemieckich miejsc upamiętniania spoza głównego szlaku, znaczonego takimi nazwami, jak Dachau, Bergen-Belsen czy Ravensbrück. Jest tym, który zadał sobie trud odszukania tych zapomnianych miejsc z powodów osobistych, ale - pisząc o nich - chce sprawić, by zaistniały w świadomości czytelników. Tym samym 
tekst Krótkiego przystanku w drodze z Auschwitz „staje się swego rodzaju lieu de mémoire, «żywym archiwum», przeznaczonym do transmisji zapomnianej przeszłości”. Jego celem jest „performatywne, pojetyczne wywoływanie z niepamięci (miejsc, ludzi, rzeczy), ponowne wprowadzanie do obiegu społecznego i prowokowanie dyskusji”. Ponadto „literatura widziana jako lieu de mémoire często wydobywa i ujawnia wyparte pamięci lokalne lub narusza normatywne wyobrażenia zbiorowych kultur pamięci"3. Tę funkcję opowieść Rosenberga pełni również $\mathrm{w}$ odniesieniu do tych wyobrażeń mnemicznych, które dotyczą stosunkowo niedawnej przeszłości Szwecji, jako że pierwszymi odbiorcami tekstu byli jego rodacy. Szwedów cieszyła wszak „wojenna koniunktura", a przerażał "kryzys pokojowy” [KP, s. 91], bo „[p]łonący świat” był poza ich "polem widzenia" [KP, s. 79]. Rychło zresztą mogli się na powrót radować, bo tego, co produkowali - choć nie były to już czołgi i wozy opancerzone - „wymagała odbudowa [...] spalonego świata” [KP, s. 79]. Do pomocy w tej produkcji potrzebni byli cudzoziemscy robotnicy.

Po tużpowojennych szwedzkich "obozach dla obcokrajowców" nie został żaden ślad poza nagrobkami z polskimi i żydowskimi nazwiskami na okolicznych cmentarzach. $Z$ archiwalnych numerów lokalnych gazet Rosenberg dowiaduje się między innymi o tym, że pensjonariuszy tych obozów nazywano też, nie wiedzieć czemu, uchodźcami albo - gdy deklarowali wolę powrotu do swojej ojczyzny - repatriantami. Bywali też transmigrantami, kiedy chciano podkreślić, że w idealnym państwie, do którego trafili, przebywają tylko czasowo i tym samym uspokoić tych, którzy obawiali się masowego napływu elementu obcego kulturowo, ze szczególnym uwzględnieniem Żydów, nienawykłych przecież do pracy innej niż kupiectwo i krawiectwo (albo do żadnej pracy, to Dawid Rosenberg usłyszał później od szwedzkiego robotnika, bo „zajmują się lichwą i pasożytnictwem” [KP, s. 271]). Gazety z połowy lat czterdziestych były też podstawowym źródłem informacji o dziwnych albo zatrważających zachowaniach niektórych „uchodźców Czerwonego Krzyża" i przygnębiających warunkach panujących w tych obozach: o zakazie ich opuszczania, gwarantowanym przez uzbrojonych strażników, izolacji od niechętnego otoczenia, bezczynności, braku empatii ze strony części personelu, sprowadzającego problemy byłych więźniów obozów koncentracyjnych do "nieprzyzwyczajenia do szwedzkiej kuchni” - zwłaszcza do krwawej kiszki, klopsików rybnych i zwyczaju "słodzenia wszystkich dań” [KP, s. 168] - oraz uważającego, że obserwowane u niektórych pensjonariuszy objawy psychozy więziennej czy głodowej to poobozowe zdziczenie: brak

3 E. Rybicka, Geopoetyka. Przestrzeń i miejsce we współczesnych teoriach i praktykach literackich, Kraków 2014, s. 317-318. 
kultury. Wspomnianą tu już przeze mnie „obawę, że mrok niesiony przez tych ludzi zainfekuje światłe społeczeństwo, które ich otacza" [KP, s. 169], dostrzega Rosenberg nawet w wypowiedziach tych autorów, którzy próbują zrozumieć i wyjaśnić niepokojące zachowania przybyszów.

W listach pisanych przez Dawida Rosenberga do przyszłej matki autora, która po wyzwoleniu KL Stutthof wróciła do Łodzi, nie ma żadnych skarg. Po tym, czego bohater opowieści doświadczył wcześniej, obozy Öreryd i Furudal oraz cała Szwecja - kwitnący „kraj bezkresnych lasów” [KP, s. 191] i nieograniczonych możliwości, „w którym nie tylko nie ma antysemityzmu, ale i nie ma w ogóle kwestii żydowskiej" [KP, s. 172] - jawiły się jako raj. Rajska była też szwedzka przyroda, opisywane w listach urzekające krajobrazy. Ten ton, jak pisze autor, "przeważnie na siłę optymistyczny” [KP, s. 180], służył przede wszystkim przekonaniu adresatki listów do podjęcia starań o wyjazd do Szwecji, do której w końcu ją wpuszczono, ale tylko dlatego, że podała się za obywatelkę polską "pochodzenia niemieckiego" [KP, s. 205].

Po opuszczeniu Furudal Dawid Rosenberg przenosi się do Alingsäs w prowincji Västra Götaland, albo „raczej do ziemi niczyjej, między światem zburzonym a innym, jeszcze nierzeczywistym" [KP, s. 184], gdzie pracuje w zakładach włókienniczych, by w końcu poniekąd wbrew woli osiąść w Södertalje, niedaleko stolicy. Zatrzymuje się tam dlatego, że „już zaczyna odczuwać potrzebę przynajmniej dłuższego przystanku" [KP, s. 10] w tej podróży, której nigdy nie zdoła uznać za zakończoną, a pobytu i pracy „na obszarze Wielkiego Sztokholmu, Göteborga i Malmö" [KP, s. 220] mu zabroniono. Do Polski wracać nie chce, bo "tam nie ma już niczego ze świata, który kiedyś uczynił swoim. [...] Nawet grobów" [KP, s. 264]; poza tym słyszał o pogromach w Krakowie i Kielcach. Państwa inne niż Szwecja też nie wchodziły wtedy w grę.

W 1946 roku niewiele jest krajów, do których można się udać, Palestyna i USA są dla żydowskich imigrantów praktycznie zamknięte, Ameryka Południowa jest za daleka i skomplikowana, Australia - daleka i droga, Europa - zamknięta tak samo jak przed wojną [KP, s. 193].

To właśnie Södertalje, siedziba firmy Scania, rozkwitającej i ciągle żądającej nowych robotników, w której ojciec autora znajdzie degradujące w jego odczuciu zatrudnienie jako monter rur i wkrótce okaże się mistrzem w ich „wyginaniu i spawaniu” [KP, s. 218], jest trzecim, obok obydwu Rosenbergów, bohaterem Krótkiego przystanku w drodze z Auschwitz. Jest Miejscem, tak właśnie, wielką literą, zapisywanym i ukazywanym w różnych, ciągle zmieniających się odsłonach - geo- i topograficznych, krajobrazowych (wizualnych, dźwiękowych, zapachowych), historycznych, ekonomicznych, spo- 
łeczno-kulturowych, obyczajowych i, co najważniejsze, afektywno-doświadczeniowych - oraz częścią, także wyróżnianego wielką literą, rodzicielskiego Projektu oswojenia obcej przestrzeni, którego ważnym elementem okazał się, wedle autora, on sam.

Södertalje jest dla niego pierwszym miejscem auto/bio/geo/graficznym ${ }^{4}$. Tam się urodził i dorastał, tam „na niewielkim spłachetku ziemi między mostem kolejowym a Morskim Kąpieliskiem, portem i wałem kolejowym czyni świat swoim własnym" [KP, s. 34] - świat, który miał „swoje geograficzne centrum $\mathrm{w}$ otynkowanym na jasnożółto dwupiętrowym bloku z dwiema klatkami schodowymi i osiemnastoma mieszkaniami poniżej peronu pierwszego stacji kolejowej" [KP, s. 20]. Dlatego pierwszym, dziecięcym wspomnieniem są, jak pisze:

pociągi, które nigdy nie stają i nigdy się nie kończą, tylko wiecznie stukoczą po nocach $\mathrm{w}$ swoich ciasno sczepionych karawanach krytych wagonów towarowych i lor [...]. Pamiętam je głównie dlatego, że to one jako pierwsze budzą mnie, gdy w oknach trzęsą się szyby, a złącza szyn tłuką o koła i trzaskające błyskawice z podwójnych lokomotyw wdzierają się przez zasłony, i stęchły zapach chemikaliów i zgnilizny stacza się ku nam z peronów, i wpada do naszych łóżek i snów [KP, s. 22].

Świadom zniekształcającej, porządkującej „mądrości post-factum, która jest „wszechobecna i nieuchronna i zdradliwa” [KP, s. 30-31], będzie próbował skrupulatnie oddzielać niepewnie zapamiętane dziecięce doznania od tego, co można wysłowić jako doświadczenie Miejsca. Dlatego tak często w jego opowieści powtarzają się frazy: „o wiele później”, „dopiero później”, "dopiero dużo później”, „o całe życie później”, w niektórych fragmentach tekstu otwierające wiele kolejnych akapitów. Dopiero później zatem połączy to pierwsze wspomnienie $\mathrm{z}$ obrazem innych pociągów - tych, którymi do kolejnych obozów byli "dostarczani” jego rodzice. „Dopiero później znajdą się słowa na rozpacz i strach, a jeszcze później na koszmary, które tapetowały to mieszkanie z oknami na tory kolejowe" [KP, s. 32]. Później też pojawi się myśl o sprawczej roli owego Miejsca - jego (współ)udziale w samobójczej śmierci ojca.

Wcześniej był jedynie „raj przy jarzębinowej alei” [KP, s. 40], lęk przed mostem kolejowym nad kanałem, który stanowił „bramę do miejsca, [...] groźną granicę rozdzielającą dom i świat" [KP, s. 7], wyprawy do Morskiego Kąpieliska, do lasu, stary port niemal w środku miasta, dobrze znana droga do szkoły.

4 Zob. E. Rybicka, Geopoetyka, s. 420-422. 
Most to jest na wskroś złowrogi pasaż, zimny szkielet z nabitymi nitami stalowych belek, poskręcanych i zespawanych w trójkąty i nieforemne łuki, na podobieństwo pary kościstych ramion, wyrastających z czterech wielkich cokołów po obu stronach zwodzonego przęsła nad torem wodnym [KP, s. 7].

Morskie kąpielisko jest światłem w tym świecie, który próbuję uczynić swoim. Całkiem dosłownie światłem, ponieważ właśnie w stronę kąpieliska las rzednie i niebo wciska się między pnie sosen, i biały piasek wyciąga się ku migoczącej słońcem wodzie. Przy Kąpielisku jest zawsze jasno, czy może ułomki pamięci pobłyskują tu ze szczególną mocą [KP, s. 214].

W czynieniu tego świata swoim usilnie pomagali chłopcu rodzice. To była część Projektu. „Dziecko wrasta w Miejsce najpierw przez Język” [KP, s. 24]. Dostało zatem imię Göran, „które jest jak wymyślone specjalnie po to, by odróżnić obcych od miejscowych. Probierzem jest szczególna intonacja długiego ö" [KP, s. 23]. Szwedzki szybolet miał tu stanowić stuprocentowe zabezpieczenie przed wyobcowaniem. Szwedzki był językiem, w którym mówiono do tego dziecka w domu nawet wtedy, gdy był to jeszcze język niemal obcy rodzicom. „Nic nie może oddzielać Dziecka od Miejsca. [...] Nic, co by mogło pozbawić Dziecko punktu oparcia dla nich wszystkich" [KP, s. 23]. Na tym polegał Projekt: to ono „uczyni Miejsce swoim miejscem i umożliwi im w ten sposób nowy świat" [KP, s. 19]. Ta formuła jest stale w tekście przywoływana w rozmaitych, nieznacznie zmienionych wariantach.

Ale o wiele później dorosły syn zrozumie, że ostatni świat rodziców, który - choć naznaczony śmiercią - „wciąż jeszcze jest zakorzeniony w żyjących ludziach i wspomnieniach" [KP, s. 55], więc ,jeszcze ma jakąś przeszłość i przyszłość" [KP, s. 54], to Litzmannstadt Getto. Pojmie, że po Auschwitz dla takich jak jego ojciec żadnej przyszłości już nie było, że zostali skazani na bezdomność i absolutne niezrozumienie, które nazywa „pomieszaniem języków" (to kolejna formuła wielokrotnie powtarzana w tekście, współtworząca jego swoisty, melancholijny rytm), bo - jak tłumaczy -

jesteśmy w stanie zapuścić korzenie gdzie indziej tylko pod warunkiem, że wciąż istnieje jakieś żywe powiązanie z miejscem i światem, i językiem, które nas kształtowały.

Lecz dla takich jak ty nie ma takiego powiązania. Nie ma miejsca, które Cię ukształtowało, ani tych ludzi i języka, nie ma także pamięci. Między tobą a światem, który kiedyś uczyniłeś własnym, wznosi się mur bólu, przez który pamięć nie zdoła się przebić [KP, s. 303].

Czarnowłosy malec nie mógł pomóc ojcu w otwieraniu horyzontów na przyszłość. Mimo rodzicielskich starań przeczuwał, że jest obcy - że różni 
się od Szwedów - i wstydząc się tej różnicy pozwalał Miejscu, by "odwracało" go od bliskich. "Jakby się bał, że coś mu odbiorą, naruszą jego pozycję" [KP, s. 39-40] w świecie, który wziął w posiadanie, że na zawsze wtrącą go w swoją, niechcianą inność z kaleczoną szwedczyzną, chanukowym świecznikiem postawionym obok bożonarodzeniowej choinki i krewnymi z Izraela, z którymi rozmawiają po polsku, wtrącając czasem jakieś słowo w jidysz. Jako dorosły wstydził się trochę swego dziecięcego wstydu, choć go rozumiał. Próbując dociec przyczyn klęski Projektu, opowiada historie równoległe Dawida Rosenberga i Södertalje. Nigdzie, co prawda, nie mówi wprost o paralelizmie losów tych dwu bohaterów swojej opowieści, ale niepodobna nie zauważyć łączących je analogii. Konstatację, że miejsce, w którym uczy się "nazywać świat, to wykolejone marzenie planistów” [KP, s. 29] można odnieść zarówno do miasta, jak i do związanego z nim zamysłu rodziców. $Z$ jednej strony bowiem dowiadujemy się na przykład o kresie planów związanych z budową własnego domu; o fiasku kompulsywnych dążeń ojca zmagającego się z postępującą, z powodzeniem skrywaną przed Göranem i jego młodszą siostrą, chorobą psychiczną - do osiągnięcia jakiegoś wymiernego sukcesu zawodowego, mającego usprawiedliwić fakt cudownego ocalenia; o incydentalnych, ale niweczących nadzieję na prawdziwe zadomowienie ekscesach antysemickich czy o porażce $\mathrm{w}$ staraniach o niemieckie "zadośćuczynienie za trwały uszczerbek na zdrowiu doznany na skutek nazistowskiego terroru" [KP, s. 288], bo „[w] [wewnętrzne rany nie robią wrażenia na wyznaczonych i opłacanych przez niemieckie państwo lekarzach orzekających [...], którym powierzono misję rozstrzygania, komu z ocalonych należy zadośćuczynić, a komu nie" [KP, s. 281]. Z drugiej zaś strony autor opowieści odnotowuje takie na przykład wydarzenia, jak pożar, a potem zamknięcie chluby Södertalje, czyli Morskiego Kąpieliska, z powodu zakażenia bakteriami coli i chemikaliami spływającymi do jego wód z pobliskich fabryk, co przekreśliło marzenia o zbudowaniu wokół niego przyciągającego turystów kurortu, czy rozpisuje się o nigdy nieziszczonych wizjach urbanistycznych i architektonicznych, mających tak odmienić miasto, by stało się czymś więcej niż tylko punktem przelotowym na drodze ze Sztokholmu do wielkiego świata.

„O wiele później zrozumiałem, że to jest w jakiś sposób specjalność tego miejsca. Że tu nic nigdy nie wychodzi tak jak w planach" [KP, s. 30] - pisze Göran Rosenberg już w pierwszym rozdziale Krótkiego przystanku w drodze z Auschwitz, zatytułowanym Miejsce właśnie. Tak oto - uprzedzając intymistyczno-reportażowy raport o klęsce wszystkich projektów z związanych tymże miejscem - desperacko, bo ma przecież świadomość retroaktywnej mocy swoich narracyjnych działań, obarcza je współwiną za śmierć ojca. 


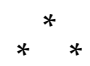

Droga, jaką do Auschwitz i z Auschwitz do Szwecji, „małego kraju poza światem" [JNM, s. 357], przebyła protagonistka powieści Axelsson, była znacznie krótsza i mniej skomplikowana niż droga Dawida Rosenberga: „cygańskie obejście” za jakąś nienazwaną wioską położoną "chyba w Bawarii” [JNM, s. 287] - chyba nieopodal Monachium; niezlokalizowany przestrzennie przyklasztorny sierociniec, gdzie przebywała w tym krótkim okresie, kiedy to Niemcy rozważali hipotezę o aryjskim pochodzeniu Romów i brali pod uwagę możliwość „reedukacji” przynajmniej niektórych romskich dzieci; "obóz cygański” w Auschwitz; Ravensbrück; szpital gdzieś w Danii; bardzo gościnne, troszczące się o „uchodźczynie Czerwonego Krzyża” Aneby już w Szwecji - tam Miriam odbywała kwarantannę; pobliskie Jönköping i wreszcie niedalekie Nässjö, w którym szczęśliwie przeżyła sześćdziesiąt osiem lat. Państwo szwedzkie przyjęło ją tylko dlatego, że była uważana za Miriam Goldberg, jedną z żydowskich ofiar obozów koncentracyjnych. Romowie - co wtedy, gdy rozstrzygały się jej losy podejrzewała, ale dowiedziała się o tym znacznie później - nie mieli prawa wstępu na jego terytorium do 1954 r. Jako Żydówkę z dobrego domu, której cała rodzina została zgładzona, przygarnęła młodziutką Miriam nauczycielka miejscowego liceum, prawdziwa, wykształcona szwedzka dama, działaczka Czerwonego Krzyża, Hanna Adolfsson.

Bohaterka powieści Axelsson naprawdę była "cygańskim mishlingiem” i nazywała się Malika; Miriam stała się przez przypadek. Skatowana przez współwięźniarki, czeskie komunistki, podczas transportu z Auschwitz do Ravensbrück, w obawie przed karą zamieniła swoją podartą w bójce sukienkę na oznakowane, czego nie zauważyła, ubranie zdjęte z jakiejś zmarłej dziewczyny. Okazało się, że ta dziewczyna była Żydówką. Inna Żydówka, znająca zmarłą, doradziła, by Malika wydrapała ze swego tatuażu literę Z („identyfikator" der Zigeuner) i kilka cyfr niezgodnych z numerem nadanym tamtej dziewczynie. W ten sposób została zmuszona przyjąć jej tożsamość - ukryć się za nią. Tak oto opowiada o tym po latach swojej wnuczce, Camilli:

stałam się Miriam Goldberg. Na dobre i złe. Niemcy byli wredni wobec wszystkich z żółtymi gwiazdami, wredni i podli, a więźniowie funkcyjni, kapo, opróżniający latryny i inne uprzywilejowane typki, byli gorsi wobec Cyganów, a to przecież z innymi więźniami miało się do czynienia. Więc dalej byłam Miriam [JNM, s. 286].

Przetrwać nie tylko w obozie, ale też w Szwecji mogła jedynie za cenę kłamstwa - przez całe życie zatem „udawała Żydówkę, chociaż nie miała pojęcia, 
czym jest żydowska wiara" [JNM, s. 32]. Wszystko, czego doświadczała na swojej drodze z Auschwitz, utwierdzało ją w słuszności dokonanego wyboru. Od pogardy dla Romów nie były wolne nawet najlepsze, najszlachetniejsze osoby, które spotkała na tej drodze. Tropiła wszelkie przejawy tejże pogardy, tak jak Göran Rosenberg rejestrował wszelkie przejawy szwedzkiego antysemityzmu. Wiedziała, że jako Cyganka nigdy i nigdzie nie mogłaby liczyć na pomoc. Ale zapisany na ciele znak piętnował ją podwójnie również we własnych oczach: jako poniewieraną Romkę, którą była, i jako tchórza, kłamcę i zdrajczynię rodzimego etnosu, którą się stała. Nawet po latach ów znak przypominał o konieczności wymazywania jego śladów odprawiania codziennych rytuałów idealnej mimikry, które opanowała do perfekcji, samodyscyplinowania się wmawianymi sobie zaklęciami: "Jedyne, czego chcesz, to wziąć się w garść. Chcesz dalej milczeć i się uśmiechać. Milczeć i uśmiechać się, jak milczałaś i uśmiechałaś się przez sześćdziesiąt osiem lat" [JNM, s. 148].

Pozbawiona w zasadzie spektakularnych zdarzeń akcja powieści Axelsson rozgrywa się w ciągu kilku godzin, w dniu, w którym Miriam - równie „stonowana" jak jej dawna opiekunka, która nauczyła ją powściągać emocje, nobliwa starsza pani - obchodzi wymyślone osiemdziesiąte piąte urodziny. Wymyślone, bo przecież naprawdę "[n]ie wie, którego dnia się urodziła, nie wie nawet, w którym roku" [JNM, s. 32]. W zgromadzonych rano przy jej łóżku członkach rodziny niepokój budzi zdanie, wypowiedziane pod wpływem impulsu, nad którym tym razem nie zdołała zapanować: „Ja nie jestem Miriam" [JNM, s. 24]. To ono skłania jej przybraną wnuczkę i pasierba do zadania pytań przedtem niezadawanych. Te po raz pierwszy postawione pytania o przeszłość kobiety, którą uważają za swoją matkę i babcię, wyzwalają ciąg obrazów, dzięki którym i my możemy tę przeszłość lepiej poznać. Nie stwarzały takiej możliwości wcześniej przywoływane w powieści kompulsywnie nawiedzające Miriam traumatyczne przebłyski pamięci zdarzeń z minionych, mniej lub bardziej odległych czasów, których nie chciała pamiętać. Zawsze broni się przed tymi widmami, zmuszając się do powrotu tam, gdzie jest jej dom, do swojej „kryjówki” - do bezpiecznego widoku za oknem:

napawa się tym widokiem. Białym bzem, który wciąż kwitnie. Alejką, którą wczoraj grabiła. Króciutkim odcinkiem Strandvägen. Trawą po drugiej stronie. I Ingsbergssjön. I konturami Nässjö. I miejskim parkiem. I ratuszem. I wieżą kościoła w oddali, nieustannie celującą w niebo. Nagle pojawia się inne miasto i inna kościelna wieża i przesłania to, co powinna widzieć. Nie godzi się na to, nie pozwala mu się wcisnąć i wybić na pierwszy plan [...], bo przecież nie jest w Ravensbrück i nie patrzy na wieżę kościoła w Fürstenbergu. Jest w Nässjö [NM, s. 14]. 
Focus narracji w Ja nie jestem Miriam - zarówno w retrospektywnym, jak i, z niewielkimi odstępstwami, w aktualnym planie czasowym - stanowi świadomość i psychosomatyczne doświadczenie bohaterki. Sceny z jej przeszłości udostępniane są w dwojakim trybie: jako wygłoszone odpowiedzi na pytania oraz jako sprowokowane tymi pytaniami komentarze w myślach niekiedy bardzo rozbudowane, przeradzające się w ciągłą opowieść o jakichś wydarzeniach. Granica między tymi trybami jest płynna. Podstawowy stylistyczny modus tej narracji we fragmentach retrospektywnych (czyli mowa pozornie zależna $\mathrm{w}$ wersji, $\mathrm{w}$ której o stałej mediacji nietożsamego $\mathrm{z}$ postacią narratora świadczy jedynie forma gramatyczna) sprawia, że czasami nie sposób rozstrzygnąć, czy bohaterka jeszcze mówi do współobecnego słuchacza, czy już tylko milcząco wspomina to, czego nadal nie może, bo nie potrafi lub nie chce, wypowiedzieć. Modus ten służy ponadto iluzji obcowania z głosem z zewnątrz, spoza kultury, która przez lata wzbraniała się przed wysłuchaniem ocalałych - przybyszów z innego świata. Mamy tu zatem do czynienia z sytuacją różną od tej z Krótkiego przystanku w drodze z Auschwitz. Tam narrator w żaden sposób nie kryje swojego usytuowania; to, co pisze o doświadczeniu ojca jest jawnym wytworem autorskich poszukiwań archiwalnych i empatycznej wyobraźni.

Podobnie jak Rosenberg, Axelsson poprzedziła pracę nad powieścią nie tylko historycznymi studiami nad podjętymi w niej trudnymi tematami (do tekstu dołączyła rozbudowaną listę źródeł, z których korzystała), ale też odwiedziła wszystkie miejsca, o których chciała napisać. „W Nässjö” - wspomina w Postscriptum - wystarczył jej „samotny spacer wokół Ingsbergssjön, taki, jaki odbyły Miriam i Camilla, podczas którego obmyślała [...], jak to wszystko poukładać $\mathrm{w}$ przestrzeni miasta - co jest przywilejem autora powieści" [JNM, s. 471-472]. I mimo iż - tym razem znowu inaczej niż Rosenberg, który ekskursom przestrzennym, przypominającym akrybiczo-melancholijne deskrypcje Sebalda, poświęca bardzo dużo uwagi - autorka Ja nie jestem Miriam nie eksponuje zanadto tej przestrzeni, poprzestając na jej najbardziej wyrazistych znakach, to fakt, że bohaterka powierzyła idyllicznym właściwościom miejsca, w którym żyła, rolę swoistego zwornika bezpieczeństwa, sprawia, że nabiera ono szczególnego znaczenia. Pewności, że jest to jej miejsce, sprzyjała historia - cudza historia, jednakże afirmowana nie dlatego, że własnej Malika-Miriam została pozbawiona (o tym, kim są Zigenare czy Judar dowiedziała się z trzydziestoośmiotomowej encyklopedii Nordisk familjebok, którą znalazła w bibliotece swojej szwedzkiej opiekunki). W Nässjö specjalną wartość miał dla niej kamień pamiątkowy ku czci lokalnych bohaterów, umieszczony w ,[r]ajskim miejskim parku” [JNM, s. 277], by sławić ich czyny z wojny w roku 1612. 
To jej sekretny monument [...], memento, że jednak istnieje takie miejsce, które daje poczucie bezpieczeństwa i niesie pociechę, choćby nawet pod pewnymi warunkami. Wciąż pamięta swój zachwyt, gdy [...] sześćdziesiąt pięć lat temu [...] zobaczyła go pierwszy raz [...], kiedy zdała sobie sprawę, że w Nässjö od trzystu trzydziestu sześciu lat panował pokój. Uznała, że to miasto jest najlepszym schronieniem na ziemi, że nigdy go nie opuści, że przylgnie do tego miejsca na zawsze, bez względu na koszty [JNM, s. 154].

Oczywiście na krótko je opuszczała, odbywała ze szwedzkim mężem egzotyczne podróże, ale nigdy tak naprawdę nie interesowało jej otwarcie na świat - na inne przestrzenie, skrajnie odmienne od tych, które znała wcześniej: zamkniętych, odgrodzonych od świata zewnętrznego. Taką odizolowaną przestrzenią był nie tylko obóz cygański w Auschwitz i obóz Ravensbrück, ale też „cygańskie obejście”, w którym się urodziła i wychowała. Już w sierocińcu - kolejnym miejscu odciętym od świata - cieszyła ją, mimo obaw o los dorosłych krewnych i częstych batów, wolność od dawnych uciążliwych obowiązków, przypadających w udziale romskim dziewczynkom („nie musiała dzień w dzień gotować ani ciągle robić kawy, nie musiała prać, prać i prać w kilku wodach i w różnych kadziach" [JNM, s. 37]) i, to przede wszystkim, możliwość nauki, której nigdy wcześniej nie miała.

„Dźwięki z kuźni. Metal uderza o metal. Syk. Śmiech. Głosy krewnych, niskie męskie, piskliwe kobiece. Migotliwy śmiech dzieci perlący się na podwórzu" [JNM, s. 35] - to niemal wszystko, co zapamiętała z wczesnego dzieciństwa. I jeszcze dzień, w którym te „zasmarkane bachory, które [jak uważali Niemcy] wyrosną na złodziei i oszustów, sutenerów i fałszerzy [...], jeśli nadal pozostaną pod wpływem takich rodziców", brutalnie rodzicom odbierano, rozpaczliwy płacz dzieci i matek, wrzask Kripo i wyraz twarzy dziadka.

Malował się na niej gniew i wstyd, zdumienie i rozpacz. [...] Dziadek myślał, że ocali całą rodzinę, bo kiedyś był niemieckim żołnierzem, a poza tym miał stałe miejsce zamieszkania. Był właścicielem domu i pralni, owszem, w opłakanym stanie, ale zawsze. A że na podwórzu stoi kilka wozów, nie powinno mieć większego znaczenia. To przecież tylko krewni, którzy przyjechali z wizytą i nikomu nie wadzą, bo dom i pralnia stoją na uboczu, w odległości ponad kilometra od wsi [JNM, s. 36-37].

Ten stojący na uboczu, gwarny, pełen ludzi dom był niegdyś całym światem Maliki, ale wiele wskazuje na to, że albo - inaczej niż Dawid i Göran Rosenbergowie w swoich pierwszych światach - nie zdążyła się w nim zakorzenić, albo miała wątpliwości co do natury związków, jakie ją z nim łączyły. Raz tylko była dumna ze swoich pobratymców: wtedy, gdy w Auschwitz 
wzniecili bunt, gdy oni jedni stawili opór SS. Jednakże mimo nie w pełni wyartykułowanego sprzeciwu wobec samookreślania się przez więzy krwi i utraty poczucia przynależności do romskiej wspólnoty, ilekroć słyszy opinie deprecjonujące Cyganów (leitmotywicznie powtarzane: „Cyganie, wiadomo co to za jedni" to najłagodniejsza $\mathrm{z}$ nich), czuje się upokorzona i zagrożona, cierpi. Cierpi wspominając zmarłego w Auschwitz braciszka, poddawanego „medycznym" eksperymentom przez dr. Mengele, i zatłuczoną na śmierć czternastoletnią kuzynkę. I wstydzi się, że „[z]dradziła tych dawno umarłych. Zdradziła swój naród i język, dziadka i ojca, ciotki, wujów i kuzynów, których imion i twarzy już nie pamięta", zdradziła „tę, którą była" [JNM, s. 431]. Stąd stale przez nią ponawiane pytanie - wielokrotnie, $\mathrm{w}$ rozmaitych konfiguracjach, przywoływane $\mathrm{w}$ tekście powieści - o to, kim jest teraz. I w końcu (gdy wreszcie zaczęła mówić o swojej przeszłości, co zmusiło ją do podjęcia po Freudowsko-Ricoeurowsku rozumianej „pracy pamięci” i otworzyło na „pracę odżałowywania" ${ }^{5}$, której efektem powinna być przynajmniej możliwość pogodzenia się z samą sobą) niepewna próba rezygnacji z niemożliwej autodefinicji w kategoriach narodowościowych. Wedle tych kategorii, nie będąc już Romką, musiałaby pozostać „nikim”. Malika-Miriam zyskuje jednak świadomość niekonieczności homogenicznej samoidentyfikacji w narzuconych z zewnątrz, wspólnotowych ramach; tym, co wybiera u schyłku życia, jest tożsamość ujmowana procesualnie i indywidualistycznie.

Ciekawe, że w sytuacji, gdy już oswojona, wydawałoby się, szwedzka przestrzeń przestaje wywiązywać się z roli bezpiecznej kryjówki, Axelsson opisuje tę przestrzeń ze znacznie większą starannością niż inne miejsca, w których lokowała swoją bohaterkę - z bardzo dokładnym wyszczególnieniem charakterystycznych punktów, nazw ulic i ich orientacji na planie miasta. Dzieje się tak, kiedy opowiada o rozruchach zwróconych przeciw tattare w lipcu 1948 r., kiedy to „[d]obrzy mieszkańcy Jönköping wyszli latem na ulicę, żeby [ich] przepędzić" [JNM, s. 149] - tego samego Jönköping, w którym trochę wcześniej policja przetrzymywała w areszcie „uchodźców Czerwonego Krzyża”, którzy podnieśli bunt w obozie Öreryd i podjęli protestacyjny marsz na Sztokholm. Pisze o tym Rosenberg. Odtwarzając klimat społeczny Szwecji lat czterdziestych wspomina też pogrom tattare - którzy mogli być obcokrajowcami o ciemniejszej skórze, romsko-szwedzkimi mieszańcami albo po prostu znienawidzonymi Romami. Miriam jest jedną z ofiar tych rozruchów, czego nie wyjawia, bo fakt, że i ona została brutalnie zaatakowana przez ich uczestników, mógłby wzbudzić podejrzenia opiekunów co do jej skrywanej tożsamości. Milczy zatem i o tym, tak jak

5 Zob. P. Ricoeur, Pamięć, historia, zapomnienie, przeł. J. Margański, Kraków 2012, passim. 
przez lata milczała o całej swojej przeszłości, w czym pomagał jej brak pytań o nią, motywowany zarówno taktem i przekonaniem o terapeutycznej mocy zapominania, jak też obojętnością i niechęcią do wysłuchiwania opowieści o "okropieństwach" - zapewne również tych wyrządzonych Romom przez Szwedów - bo mogłyby "obrócić wniwecz [ich] pieczołowicie budowaną nieskazitelność, a tego naturalnie Szwedzi by nie znieśli" [JNM, s. 282]. Ten brak zainteresowania okazał się najlepszym sprzymierzeńcem realizowanego przez bohaterkę projektu na przetrwanie w „najlepszym z możliwych krajów" - w miejscu, które dało jej kruche, stale zagrożone utratą, poczucie bezpieczeństwa. Dla Dawida Rosenberga natomiast konieczność milczenia i coraz powszechniejsza $\mathrm{z}$ upływem lat niepamięć były jedynie źródłem udręki, która doprowadziła go do samobójczej śmierci. Jego synowi - wsłuchanemu we własne doświadczenia cudownie rozszerzającej się przestrzeni, $\mathrm{w}$ której dorastał i wpatrzonemu $\mathrm{w}$ otwierające się przed nim horyzonty - dopiero po latach, już „w trzeźwych salonach późnego rozumienia”, jak powtarzał za Benjaminem [KP, s. 33], objawiła się sprawcza, destrukcyjna, moc Miejsca, do którego ojciec trafił w swojej drodze z Auschwitz. Jednakże w jego przypadku i w owych czasach - w latach pięćdziesiątych i sześćdziesiątych - taką moc można by przypisać niemal każdemu miejscu na ziemi, bo świat chciał wtedy patrzeć „w przyszłość nie oglądając się za siebie” [KP, s. 276]. Jedną z formuł, przy pomocy których Göran Rosenberg próbował nazwać ówczesną sytuację ocalałych, było, wspomniane już tu przeze mnie, "pomieszanie języków".

tak nazywam - pisał - niewidzialną ścianę wznoszącą się między wami a Miejscem, nie tyle ścianę między językami, ile [...] między światem, który nosicie w sobie, a światem, który chcecie uczynić swoim; ścianę, której nie może przeniknąć żaden język. Słowa już przecież tam są - getto, obóz śmierci, komora gazowa, zagłada, eksterminacja - tylko że nikt ich nie rozumie.

O ile w ogóle obchodzi ich, co one znaczą [KP, s. 239].

W drodze z Auschwitz, jaką przebyła Malika-Miriam, jeszcze większe znaczenie niż to "pomieszanie" - tak samo zdawałoby się doświadczane przez wszystkich, którzy przeżyli - miało wykluczenie jej narodu ze wspólnoty ofiar. Najbardziej bodaj dobitnym tego dowodem był brak reakcji świata na fakt, że więzionym w obozach koncentracyjnych „Romom nie zaproponowano żadnej rekompensaty. Jak oświadczyły po wojnie niemieckie władze, Romowie nie zostali wytępieni z powodów rasowych, ale dlatego, że byli kryminalistami" [JNM, s. 444]. I kryminalistami pozostali dla kulturalnych mieszkańców Jönköping i Nässjö - miejsca, które mimo wszystko bohaterka powieści Axelsson uczyniła swoim. 


\section{Bibliografia}

Axelsson Majgull, Ja nie jestem Miriam, przeł. H. Thylwe, Warszawa: Wydawnictwo WAB, 2015.

Ricoeur Paul, Pamięć, historia, zapomnienie, przeł. J. Margański, Kraków: Universitas, 2012.

Rosenberg Göran, Krótki przystanek w drodze z Auschwitz, przeł. M. Kalinowski, Wołowiec: Wydawnictwo Czarne, 2014.

Rybicka Elżbieta, Geopoetyka. Przestrzeń i miejsce we wspótczesnych teoriach i praktykach literackich, Kraków: Universitas, 2014.

\section{Swedish Places on a Road from Auschwitz: \\ a Stop and a Harbor in the Narratives by Göran Rosenberg and Majgull Axelsson \\ Summary}

The article discusses two texts. One is A Brief Stop on a Road from Auschwitz, a post memorial, non-fictional prose by Göran Rosenberg, the other - My Name is not Miriam, a novel by Majgull Axelsson. The main characters of these stories are Holocaust survivors, who after the war reach Sweden with the help of the local Red Cross. The article attempts to discover the intricate intersections between the concepts of space, time, trauma, memory and identity, as experienced during their migration.

Keywords: migration, place, traumatic history, memory, identity, Göran Rosenberg, Majgull Axelsson 